\title{
Evaluation of factors associated with patient satisfaction and mood-state in regional anesthesia
}

\author{
Rejyonel anestezide hastaların memnuniyeti ve duygu durumu ile ilgili faktörlerin \\ değerlendirilmesi
}

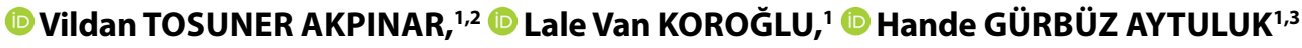

\begin{abstract}
Summary
Objectives: This study was designed to evaluate patient satisfaction with a regional anesthesia procedure and factors associated with the mood state of those patients at the time.

Methods: The study was performed with 300 patients who underwent surgery under regional anesthesia. The patients were given a questionnaire while in the recovery room about the experience of undergoing regional anesthesia to determine patient satisfaction and mood state during the procedure.

Results: The overall level of satisfaction with regional anesthesia was $82.3 \%$. The level of satisfaction was higher in the age group of 18-25 years, male gender, in patients who had a previous regional anesthesia experience, and in patients who were well informed about regional anesthesia in a preoperative anesthetic evaluation. There was a relationship between pain due to failed spinal anesthesia during surgery and dissatisfaction with regional anesthesia. Patients who were properly informed preoperatively mostly expressed the feeling of "safe." Patients who underwent urological interventions most often expressed the feeling of "comfortable". Patients underwent gynecological and obstetrical surgeries mostly expressed the feeling "excited". Patients who underwent general surgical procedures and patients who were not informed preoperatively about regional anesthesia most often reported feeling "anxious."

Conclusion: Providing adequate preoperative information to the patient about regional anesthesia will increase overall satisfaction and will assure the patient feels safe during the perioperative period.
\end{abstract}

Clinical Trial Registration Number: NCT03476278.

Keywords: Anesthesia; anxiety; outcome assessment (health care); patient satisfaction; perioperative period; regional anesthesia; surveys and questionnaires.

Özet

Amaç: Hastaların rejyonel anesteziden memnuniyetini ve rejyonel anestezi ile ameliyat olan hastaların duygu durumlarını etkileyen faktörleri araştırmak.

Gereç ve Yöntem: Çalışma rejyonel anestezi altında ameliyat olan 300 hastayı kapsamaktadır. Hastaların memnuniyeti ve ameliyat sırasındaki duygu durumları, derlenme odasında rejyonel anestezi ile ilgili yapılan bir anketle değerlendirilmiştir.

Bulgular: Tüm hastalar arasında rejyonel anesteziden genel memnuniyet 82.3\%'tü. Memnuniyet düzeyi 18-25 yaş grubun$\mathrm{da}$, erkek cinsiyette, geçmiş rejyonel anestezi deneyimi olanlarda ve preoperatif anestezi değerlendirmesi sırasında rejyonel anestezi ile ilgili uygun bilgilendirme yapılan hastalar arasında daha yüksekti. Ameliyat sırasında başarısız spinal anesteziye bağlı ağrı duyma ile rejyonel anesteziden memnuniyetsizlik arasında anlamlı bir ilişki vardı. Ameliyat öncesi uygun bilgilendirme yapılan hastalar çoğunlukla "güven" duygusunu ifade etti. Ürolojik ameliyat yapılan hastalar daha çoğunlukla "rahatlık" duygusunu ifade etti. Jinekolojik ve obstetrik cerrahi uygulanan hastalar çoğunlukla "heyecan" duygusunu ifade etti. Genel cerrahi ameliyatı yapılan hastalar ile rejyonel anestezi hakkında preoperatif yeterli bilgi alamayan hastalar çoğunlukla "korku" duygusunu ifade etti.

Sonuç: Ameliyat öncesinde rejyonel anestezi hakkında yeterli bilgilendirme, memnuniyeti arttırmakla birlikte hastaların ameliyat sırasında güvende hissetmelerini sağlayacaktır.

Klinik Çalışma Kayıt No: NCT03476278.

Anahtar sözcükler: Anestezi; anksiyete; sonuç değerlendirmesi (sağlık bakımı); hasta memnuniyeti; perioperatif periyot; rejyonel anestezi; anket araştırması.

'Department of Anesthesiology and Reanimation, Izmir Atatürk Training and Research Hospital, İzmir, Turkey

${ }^{2}$ New affiliation: Department of Anesthesiology and Reanimation, İzmir Bozyaka Training and Research Hospital, İzmir, Turkey

${ }^{3} \mathrm{New}$ affiliation: Department of Anesthesiology and Reanimation, Kocaeli Derince Training and Research Hospital, Kocaeli, Turkey

Submitted (Başvuru tarihi) 03.08.2018 Accepted after revision (Düzeltme sonrası kabul tarihi) 09.10.2018 Available online date (Online yayımlanma tarihi) 12.12.2018

Correspondence: Dr. Hande Gürbüz Aytuluk. Kocaeli Derince Eğitim ve Araştırma Hastanesi, Anesteziyoloji ve Reanimasyon Kliniği, Kocaeli, Turkey. Phone: +90 - 533 - 6515650 e-mail: handegrbz@gmail.com

(c) 2019 Turkish Society of Algology 


\section{Introduction}

Quality of health care has been defined as the degree which health services increase the probability of desired health outcome. ${ }^{[1]}$ Patient satisfaction has been defined as the baseline criterion that indicates the level at which the patient's expectations are met and which indicates the quality of medical care. ${ }^{[2,3]} \mathrm{Pa}$ tient satisfaction is an important subjective measure of healthcare quality which contributes to evaluation of the structure, process and outcome of services. ${ }^{[4]}$ Many factors contribute to patient satisfaction, including institutional structure, interpersonal relationships, and a patient' expectations. Age, gender, social insurance, educational and social statue also play role in patient satisfaction. The key factor in patient satisfaction is adequate perioperative information of the patient and communication between healthcare providers and patient or patient's kin. ${ }^{[5,6]}$

The success of regional anesthesia is influenced by several factors. Most patients expect uneventful perioperative process. Nevertheless, recovery from surgery and anesthesia is sometimes complicated by major and minor complaints including pain, nausea, vomiting and other. ${ }^{[7]}$ Although there is no scientific or clinical evidence that regional anesthesia is superior to general anesthesia, regional anesthesia has some advantages like keeping consciousness of the patient during surgery, continuation of spontaneous breathing, avoiding the loss of protective reflexes, allowing early mobilization in the postoperative period and shortening the length of hospital stay. ${ }^{[8]}$ However, the major contraindication for regional anesthesia is the patient's unwillingness.

There are few studies in anesthesia that have assessed patient satisfaction and mood-state during regional anesthesia. ${ }^{[9,10]}$ In this study, we aimed to evaluate factors associated with patient satisfaction from regional anesthesia procedure and mood-state of patients who underwent surgery under regional anesthesia.

\section{Material and Methods}

After approval of the local ethical committee and obtaining written informed consents, this prospective study was held on 300 patients who underwent surgery under regional anesthesia in Izmir Ataturk Training and Research Hospital. Data collection included patient characteristics, previous anesthetic and surgical experiences, type of surgery, perioperative critical events, and preoperative information about the anesthetic procedure. Hypotension, bradycardia, pain, nausea and vomiting were rated on an ordinal scale and dichotomized as " 1 " for presence and " 0 " for absence of any of these adverse events. At the recovery room, patients were handed a questionnaire about regional anesthesia to determine patient satisfaction and mood-state during the procedure. Patients were only able to mark one option: satisfied or dissatisfied. At the same time, they were able to mark more than one option in the part of the questionnaire about mood-state: safe, unsafe, comfortable, exited, anxious. If patient was heavily sedated and too confused to participate, the questionnaire was handed at the ward after recovery.

All patients had preanesthetic evaluation prior to the surgery. The decision of general or regional anesthesia was left to the patient's primary physician anesthesiologist. Heart rate, blood pressure, and oxygen saturation were recorded every 5 minutes during the operation, and every 15 minutes at the recovery room. Complications (bradycardia, hypotension, pain, nausea and vomiting) were recorded. Patients who underwent surgery under regional anesthesia included in the study. Patients who received regional anesthesia, but the block was inadequate because of any reason (prolonging surgery, low blockade level, patchy block) were also included in the study. Patients that are clinically significant psychiatrically ill, illiterate, and patients who received general anesthesia and patients that have speech, hearing, or understanding problems were excluded from the study.

This study was registered on www.ClinicalTrials.gov with Clinical Trial Registration Number NCT03476278.

\section{Statistical analysis}

Data were evaluated using SPSS 16.0 (Statistical Program for Social Sciences, Chicago, II, U.S). Associations of categorical variables with patient satisfaction and dissatisfaction were assessed using chi-square or Fisher's Exact tests. Significance of continuous variables were assessed with t-test and Mann Whitney $U$ test. $P$ value of $<0.05$ was used for statistically significance. 
Table 1. Patient, anesthetic and surgical characteristics of the study population. Factors associated with patient satisfaction

\begin{tabular}{|c|c|c|c|c|c|c|c|}
\hline \multirow[t]{2}{*}{ Variable } & \multirow[t]{2}{*}{$\mathbf{n}$} & \multirow[t]{2}{*}{ Incidence (\%) } & \multicolumn{2}{|c|}{ Satisfaction } & \multicolumn{2}{|c|}{ Dissatisfaction } & \multirow[t]{2}{*}{$\mathbf{p}$} \\
\hline & & & $\mathbf{n}$ & Rate (\%) & $\mathbf{n}$ & Rate (\%) & \\
\hline Total & 300 & 100 & 247 & 82.3 & 53 & 17.6 & \\
\hline \multicolumn{8}{|l|}{ Age group } \\
\hline $18-25$ & 24 & 8.0 & 23 & 95.8 & 1 & 4.2 & \multirow[t]{3}{*}{$0.017^{*}$} \\
\hline $26-35$ & 46 & 15.3 & 30 & 65.2 & 16 & 34.8 & \\
\hline $36-45$ & 89 & 29.7 & 77 & 86.5 & 12 & 13.5 & \\
\hline $46-55$ & 64 & 21.3 & 54 & 84.4 & 10 & 15.6 & \multirow[t]{3}{*}{$>0.05$} \\
\hline $56-65$ & 51 & 17.0 & 41 & 80.4 & 10 & 19.6 & \\
\hline $66-75$ & 26 & 8.7 & 22 & 84.6 & 4 & 15.4 & \\
\hline \multicolumn{8}{|l|}{ Gender } \\
\hline Female & 108 & 36.0 & 83 & 76.9 & 25 & 23.1 & $>0.05$ \\
\hline Male & 192 & 64.0 & 164 & 85.4 & 28 & 14.6 & $0.045^{*}$ \\
\hline \multicolumn{8}{|l|}{ Education } \\
\hline Primary school & 136 & 45.3 & 112 & 82.4 & 24 & 17.6 & \multirow{4}{*}{$>0.05$} \\
\hline Junior high school & 40 & 13.3 & 32 & 80 & 8 & 20 & \\
\hline High school & 74 & 24.7 & 59 & 79.7 & 15 & 20.3 & \\
\hline University & 50 & 16.7 & 44 & 88 & 6 & 12 & \\
\hline \multicolumn{8}{|l|}{ Type of surgery } \\
\hline General & 72 & 24 & 56 & 77.5 & 16 & 22.5 & \multirow{3}{*}{$>0.05$} \\
\hline Orthopedy & 60 & 20 & 51 & 85 & 9 & 15 & \\
\hline Gynecology \& obstetric & 54 & 18 & 38 & 70.4 & 16 & 29.6 & \\
\hline Urology & 114 & 38 & 102 & 89.5 & 12 & 10.5 & $0.013^{*}$ \\
\hline \multicolumn{8}{|c|}{ Past regional anesthesia experience } \\
\hline Yes & 130 & 43.3 & 115 & 88.5 & 15 & 11.5 & $0.01^{*}$ \\
\hline No & 170 & 56.6 & 132 & 77.6 & 38 & 22.4 & $>0.05$ \\
\hline \multicolumn{8}{|l|}{ Preoperative information } \\
\hline Yes & 285 & 95 & 241 & 84.6 & 44 & 15.4 & $0.001^{*}$ \\
\hline No & 15 & 5 & 6 & 40.0 & 9 & 60.0 & $>0.05$ \\
\hline \multicolumn{8}{|l|}{ Intraoperative adverse events } \\
\hline Hypotension & 72 & 24 & 61 & 84.7 & 11 & 15.2 & \multirow{3}{*}{$>0.05$} \\
\hline Bradycardia & 27 & 9 & 22 & 81.4 & 5 & 18.5 & \\
\hline Nausea-vomiting & 48 & 16 & 36 & 75 & 12 & 25 & \\
\hline Pain & 13 & 4.3 & 4 & 30.7 & 9 & 69.2 & $0.005^{*}$ \\
\hline \multicolumn{8}{|c|}{ Recovery room adverse events } \\
\hline Hypotension & 30 & 10 & 26 & 86.6 & 4 & 13.3 & \multirow{4}{*}{$>0.05$} \\
\hline Bradycardia & 36 & 12 & 30 & 83.3 & 6 & 16.6 & \\
\hline Nausea-vomiting & 19 & 6.3 & 14 & 73.6 & 5 & 26.3 & \\
\hline Pain & 32 & 10.7 & 28 & 87.5 & 4 & 12.5 & \\
\hline
\end{tabular}

\section{Results}

Patient demographics, anesthetic and surgical characteristics, and factors associated with patient satisfaction are presented in Table 1. Overall level of sat- isfaction of regional anesthesia was $82,3 \%(n=247)$. The level of satisfaction was higher in the $18-25$ years age group (95.8\%; $\mathrm{p}=0.017)$ and male gender $(85.4 \%$; $\mathrm{p}=0.045)$. There was no statistically significant differ- 
Table 2. Factors associated with patients' mood state (More than one option can be marked in the questionnaire)

\begin{tabular}{|c|c|c|c|c|c|c|c|c|c|c|c|}
\hline \multirow[t]{2}{*}{ Variable } & \multirow[t]{2}{*}{$\mathbf{n}$} & \multicolumn{2}{|c|}{ Safe } & \multicolumn{2}{|c|}{ Unsafe } & \multicolumn{2}{|c|}{ Comfortable } & \multicolumn{2}{|c|}{ Excited } & \multicolumn{2}{|c|}{ Anxious } \\
\hline & & $\mathbf{n}$ & Rate (\%) & $\mathbf{n}$ & Rate (\%) & $\mathbf{n}$ & Rate (\%) & $\mathbf{n}$ & Rate (\%) & $\mathbf{n}$ & Rate (\%) \\
\hline \multicolumn{12}{|l|}{ Age group } \\
\hline $18-25$ & 24 & 6 & 25 & 0 & 0.0 & 8 & 33.3 & 12 & 50 & 5 & 20.8 \\
\hline $26-35$ & 46 & 16 & 34.8 & 5 & 10.9 & 11 & 23.9 & 26 & 56.5 & 16 & 34.8 \\
\hline $36-45$ & 89 & 42 & 47.2 & 5 & 5.6 & 32 & 36 & 34 & 38.2 & 22 & 24.7 \\
\hline $46-55$ & 64 & 36 & 56.3 & 5 & 7.8 & 24 & 37.5 & 19 & 29.7 & 10 & 15.6 \\
\hline $56-65$ & 51 & 24 & 47.1 & 3 & 5.9 & 24 & 47.1 & 17 & 33.3 & 10 & 19.6 \\
\hline $66-75$ & 26 & 13 & 50 & 2 & 7.7 & 10 & 38.5 & 7 & 26.9 & 4 & 15.4 \\
\hline $\mathrm{p}$ & & \multicolumn{2}{|c|}{$>0.05$} & \multicolumn{2}{|r|}{$>0.05$} & \multicolumn{2}{|c|}{$>0.05$} & \multicolumn{2}{|c|}{$0.037^{*}$} & \multicolumn{2}{|r|}{$>0.05$} \\
\hline \multicolumn{12}{|l|}{ Gender } \\
\hline Female & 108 & 45 & 41.7 & 8 & 7.4 & 33 & 30.6 & 48 & 44.4 & 28 & 25.9 \\
\hline Male & 192 & 92 & 47.9 & 12 & 6.9 & 76 & 39.6 & 67 & 34.9 & 39 & 20.3 \\
\hline$p$ & & \multicolumn{2}{|c|}{$>0.05$} & \multicolumn{2}{|c|}{$>0.05$} & \multicolumn{2}{|c|}{$>0.05$} & \multicolumn{2}{|c|}{$>0.05$} & \multicolumn{2}{|c|}{$>0.05$} \\
\hline \multicolumn{12}{|l|}{ Education } \\
\hline Primary school & 136 & 64 & 47.1 & 10 & 7.4 & 57 & 41.9 & 47 & 34.6 & 32 & 23.5 \\
\hline Junior high school & 40 & 16 & 40 & 1 & 2.5 & 15 & 37.5 & 15 & 37.5 & 11 & 27.5 \\
\hline High school & 74 & 31 & 41.9 & 7 & 9.5 & 21 & 28.4 & 37 & 50 & 14 & 18.9 \\
\hline University & 50 & 26 & 52 & 2 & 4 & 16 & 32 & 16 & 32 & 10 & 20 \\
\hline $\mathrm{p}$ & & \multicolumn{2}{|c|}{$>0.05$} & \multicolumn{2}{|r|}{$>0.05$} & \multicolumn{2}{|c|}{$>0.05$} & \multicolumn{2}{|c|}{$>0.05$} & \multicolumn{2}{|c|}{$>0.05$} \\
\hline \multicolumn{12}{|l|}{ Type of surgery } \\
\hline General & 72 & 33 & 45.8 & 5 & 6.9 & 21 & 29.1 & 26 & 36.1 & 23 & 31.9 \\
\hline Orthopedy & 60 & 29 & 48.3 & 5 & 8.3 & 22 & 36.7 & 19 & 31.7 & 12 & 20 \\
\hline Gynecology \& obstetric & 54 & 18 & 33.3 & 4 & 7.4 & 13 & 24.1 & 32 & 59.3 & 12 & 22.2 \\
\hline Urology & 114 & 57 & 50 & 6 & 5.2 & 53 & 46.5 & 38 & 33.3 & 16 & 14 \\
\hline $\mathrm{p}$ & & \multicolumn{2}{|c|}{$>0.05$} & \multicolumn{2}{|r|}{$>0.05$} & & $0.014^{*}$ & & $.006^{*}$ & & $0.015^{*}$ \\
\hline Preoperative information & & & & & & & & & & & \\
\hline Yes & 285 & 134 & 47 & 17 & 6 & 106 & 37.2 & 110 & 38.6 & 60 & 21.1 \\
\hline No & 15 & 3 & 20 & 3 & 20 & 3 & 20 & 5 & 33.3 & 7 & 46.7 \\
\hline $\mathrm{p}$ & & & $.034^{*}$ & & 0.069 & & 0.14 & & 0.454 & & $0.029^{*}$ \\
\hline
\end{tabular}

ence in satisfaction levels in comparison with educational status. Patients who underwent urological interventions were more satisfied than other types of surgeries (89.5\%; $p=0.013$ ). Satisfaction levels were statistically significantly higher in patients who had previous regional anesthesia experience $(88.5 \%$; $\mathrm{p}=0.01$ ) and in patients who were properly informed about regional anesthesia in preoperative anesthetic evaluation ( $84.6 \% ; p=0.0001$ ). Perioperative hypotension, bradycardia, nausea and vomiting have no statistically significant relation with satisfaction levels. There was a statistically significant relationship between pain due to failed spinal anesthesia during surgery and dissatisfaction from regional anesthesia $(p=0.005)$. However, there was no statistically significant relation with postoperative pain and satisfaction from regional anesthesia.

Factors associated with patients' mood-state during regional anesthesia are presented in Table 2. Patients that were properly informed preoperatively mostly expressed the feeling "safe" $(p=0.034)$. Patients who underwent urological interventions mostly express the feeling "comfortable" $(p=0.014)$. Patients that are in the 26-35 years age group and patients who underwent gynecological and obstetrical surgeries mostly expressed the feeling "excited" ( $p=0.037, p=0.006)$. Patients who under- 
went general surgical procedures and patients that were not informed preoperatively about regional anesthesia mostly express the feeling "anxious" $(p=0.015 ; p=0.029)$. There was no significant relation between mood-states and gender or educational status.

\section{Discussion}

Regional anesthesia has become increasingly popular in recent years among healthcare providers with the advances in technology, and newly developed needles and local anesthetic drugs. ${ }^{[1]]}$ It has been shown that regional anesthesia has some advantages including less intraoperative bleeding and thromboembolism, decreased analgesic medication requirements and fewer side effects such as nausea and vomiting which result in shorter hospital stay and reduced cost. ${ }^{[12,13]}$ Regional anesthesia is also popular among patients because of the possibility of speaking with relatives during the immediate postoperative period, staying awake, and the absence of pain during the immediate postoperative interval. ${ }^{[9]}$ However, most of the patients have no idea what to expect during their hospitalization. This obscurity causes anxiety and dissatisfaction with the healthcare services. Patient satisfaction is a major subjective outcome measure of health care quality and states the patient's individual experiences. ${ }^{[10]}$ On the other hand, proper preoperative information of the patient and adequate communication between healthcare providers and patient or patient's kin will surely increase overall satisfaction. ${ }^{[14-16]}$ It is confirmed in this study that, patients that are preoperatively informed about regional anesthesia procedure were highly satisfied with the technique, and they mostly expressed the safety feeling. Patients who were not properly informed before the surgery mostly felt anxious.

It has been found in this study that the factors strongly associated with satisfaction are male sex, young age, urological surgeries, and previous anesthetic experience. Male gender, urological surgeries (because of shorter duration of surgery), and previous anesthetic experience are similar with the literature, ${ }^{[9,17]}$ while young age is contrary to most studies. ${ }^{[18-20]}$

It was found in a previous study that patient satisfaction was inversely proportional with the height of educational level. ${ }^{[21]}$ In our study, patient satisfaction rate was found to be higher in patients with high educational status. However, the relation between satisfaction rates and educational levels was not statistically significant.

The adequate preoperative information about possible complications of regional anesthesia and treatment methods will provide and assure patient confidence to anesthesiologist. There was no significant relevance with patient satisfaction and perioperative complications including hypotension, bradycardia or nausea and vomiting. On the other hand, intraoperative pain due to failed regional anesthesia influenced satisfaction negatively. But postoperative pain did not affect patient satisfaction.

Patients who underwent gynecological and obstetrical surgeries and the patients in the age group between 26 and 35 years were mostly feeling excited. This result could be related to the surgery type (obstetrics) that most of the parturient were in the 26-35 years age group. This is not surprising given that the vast majority of the patients in this age group were parturient who were experiencing new and complex emotions with the birth of the baby. It has been observed that patients were mostly feeling comfortable during urological surgeries, and mostly feeling anxious during general surgical procedures.

One of the strengths of this study is that we only evaluated perioperative period, not the entire hospitalization for which a variety of other factors may be important. ${ }^{[22]}$ It has been shown that patients' responses may be modified to please the staff, therefore true level of dissatisfaction may be underrepresented. ${ }^{[2,22]}$ Hence, we showed utmost attention to the confidentiality of the participants. We collected the results of the questionnaires in sealed envelopes. Limitations of this study are that it does not have a control group for comparison and does not assess long-term outcomes of regional anesthesia.

\section{Conclusion}

Adequate preoperative information of the patient about regional anesthesia will increase overall satisfaction and will assure the patient to feel safe during perioperative period. 
The authors declare that there is no conflict of interest.

Funding: The authors received no financial support for the research, authorship, and/or publication of this article.

Peer-rewiew: Externally peer-reviewed.

\section{References}

1. Donabedian A. The quality of care. How can it be assessed? JAMA 1988;260(12):1743-8. [CrossRef]

2. Lohr KN, Donaldson MS, Harris-Wehling J. Medicare: a strategy for quality assurance, V: Quality of care in a changing health care environment. QRB Qual Rev Bull 1992;18(4):120-6. [CrossRef]

3. Gill TM, Feinstein AR. A critical appraisal of the quality of quality-of-life measurements. JAMA 1994;272(8):619-26.

4. Donabedian A. Monitoring: the eyes and ears of healthcare. Health Prog 1988;69(9):38-43.

5. Westbrook Jl. Patient satisfaction: methodological issues and research findings. Aust Health Rev 1993;16(1):75-88.

6. Forrest JB, Cahalan MK, Rehder K, Goldsmith CH, Levy WJ, Strunin L, et al. Multicenter study of general anesthesia. II. Results. Anesthesiology 1990;72(2):262-8. [CrossRef]

7. Hausman MS Jr, Jewell ES, Engoren M. Regional versus general anesthesia in surgical patients with chronic obstructive pulmonary disease: does avoiding general anesthesia reduce the risk of postoperative complications? Anesth Analg 2015;120(6):1405-12. [CrossRef]

8. De Andrés J, Valía JC, Gil A, Bolinches R. Predictors of patient satisfaction with regional anesthesia. Reg Anesth 1995;20(6):498-505.

9. Vural C, Yorukoglu D. Comparison of patient satisfaction and cost in spinal and general anesthesia for lumbar disc surgery. Turk Neurosurg 2014;24(3):380-4.

10. Smrcka M, Baudysová O, Jurán V, Vidlák M, Gál R, Smrcka V.
Lumbar disc surgery in regional anaesthesia--40 years of experience. Acta Neurochir (Wien) 2001;143(4):377-81.

11. Rassias AJ, Procopio MA. Stress response and optimization of perioperative care. Dis Mon 2003;49(9):522-54. [CrossRef]

12. Scott NB, Kehlet $\mathrm{H}$. Regional anaesthesia and surgical morbidity. Br J Surg 1988;75(4):299-304.

13. Bopp KD. How patients evaluate the quality of ambulatory medical encounters: a marketing perspective. J Health Care Mark 1990;10(1):6-15.

14. Rosenzweig S. "Emergency rapport".J Emerg Med 1993;11(6):775-8. [CrossRef]

15. Björvell $H$, Stieg J. Patients' perceptions of the health care received in an emergency department. Ann Emerg Med 1991;20(7):734-8. [CrossRef]

16. Milano M, Mola E, Collecchia G, Del Carlo A, Giancane R, Visentin $G$, et al. Validation of the Italian version of the EUROPEP instrument for patient evaluation of general practice care. Eur J Gen Pract 2007;13(2):92-4. [CrossRef]

17. Myles PS, Williams DL, Hendrata M, Anderson H, Weeks AM. Patient satisfaction after anaesthesia and surgery: results of a prospective survey of 10,811 patients. $\mathrm{Br} J$ Anaesth 2000;84(1):6-10. [CrossRef]

18. Carr-Hill RA. The measurement of patient satisfaction. J Public Health Med 1992;14(3):236-49.

19. Hall JA, Dornan MC. Patient sociodemographic characteristics as predictors of satisfaction with medical care: a meta-analysis. Soc Sci Med 1990;30(7):811-8. [CrossRef]

20. Lewis JR. Patient views on quality care in general practice: literature review. Soc Sci Med 1994;39(5):655-70. [CrossRef]

21. Fitzpatrick R. Surveys of patient satisfaction: II--Designing a questionnaire and conducting a survey. BMJ 1991;302(6785):1129-32. [CrossRef]

22. Raphael W. Do we know what the patients think? A survey comparing the views of patients, staff and committee members. Int J Nurs Stud 1967;4(3):209-23. [CrossRef] 